\title{
THE REGULATORY AND COMMERCIAL ENVIRONMENT FOR FRANCHISING IN THAILAND IN THE WAKE OF THE ASEAN INTEGRATING MARKET
}

\author{
Pornchai Wisuttisak ${ }^{*}$ \\ Nguyen Ba Binh ${ }^{* *}$
}

\begin{abstract}
The franchising sector in Thailand is a fast growing economic sector which is potentially enlarged by the imminent ASEAN market integration in 2015. This leads to significant consideration on the regulatory and commercial environment which plays considerable roles for shaping and supporting the franchising sector in Thailand in the wake of the ASEAN integrating market. Thus, this paper aims to explore the current Thai regulatory and commercial environment for franchising with regard to the ASEAN single market. The paper presents a challenging issue whether there is a lack of specific law for franchising in Thailand. The paper concludes with recommendations that there should be a unified regulation which helps facilitate the development of the franchising sector in Thailand or alternatively, to confer authoritative power to the Department of Business Development to act as an agency governing and promoting the franchising sector in Thailand.
\end{abstract}

Keywords: franchising regulation, Thailand, ASEAN

* Corresponding Author, Ph.D. (UNSW), Head of Legal Training Center, Lecturer in International Trade Law, Faculty of Law, Chiang Mai University, pornchai.w@cmu.ac.th.

** Ph.D. (UNSW), Vice Dean, Faculty of International Trade and Business Law, Hanoi Law University, Arbitrator at Vietnam International Arbitration Center (VIAC) at the Vietnam Chamber of Commerce and Industry. 


\title{
PERSEKITARAN PERATURAN DAN KOMERSIL BAGI PERNIAGAAN FRANCAIS DI THAILAND DI BAWAH INTEGRASI
}

\begin{abstract}
ABSTRAK
Sektor francais di Thailand ialah satu sektor ekonomi yang kian pesat membangun dengan potensi untuk pembesaran ekoran kepastian berlakunya integrasi pasaran ASEAN pada 2015. Ini membawa kepada pertimbangan ketara dalam persekitaran peraturan dan komersil yang memainkan peranan besar untuk membentuk dan menyokong sector francais di Thailand di bawah pengwujudan pasaran integrasi ASEAN. Makalah ini bertujuan meneroka persekitaran peraturan dan komersil yang terkini di Negara Thai mengenai francais dengan menimbangkan pasaran tunggal ASEAN. Makalah membentangkan satu isu yang mencabar di mana tiada satu undang-undang tertentu untuk perniagaan francais di Thailand. Makalah diakhiri dengan cadangan bahawa peraturan tunggal diwujudkan supaya dipermudahkan pembangunan sektor francais di Thailand. Sebagai alternatif, kerajaan Thai boleh memberi kuasa berwibawa kepada Jabatan Pembangunan Perniagaan untuk bertindak sebagai agensi untuk mengawalselia dan menggalakkan sektor francais di Tha iland.
\end{abstract}

Kata Kunci: francais, Thailand, ASEAN

\section{INTRODUCTION}

The Thai franchising sector is moving forward toward a fast economic development and market integration in ASEAN. The regulation and commercial environment plays considerable roles for shaping and supporting the franchising sector in Thailand under the wake of the ASEAN integrating market. The article therefore aims to examine the current regulation and business environment for the Thai franchising sector with a consideration of the imminent ASEAN integrating market. The article highlights that while the Thai franchising sector is expanding, there is a lack of specific regulation governing the sector. This may then create a regulatory concern when there is a lack of unified applicable rules for governing franchising 
sector. The methodology adopted in this article is a legal doctrinal research which relies on a study of laws, regulations, court cases, academic articles, and documents from government and other agencies. The concept of the ASEAN Integrating Market, in this article, is defined, based on the AEC blueprint, as the processing of building a single market and production base in ASEAN. ${ }^{1}$

'Franchising', in this article, means a method of business expansion characterized by a trademark license, payment of fees, and significant assistance and control. ${ }^{2}$ The article then goes on to provide a brief overview of the Thai regulatory framework for the franchising sector. It proceeds to also discuss the Thai franchise sector under the ASEAN integrating market and international connection. The article then compares the regulatory and commercial environment relating to the Thai franchise sector with other ASEAN member countries reflecting how the lack of specific franchising law may create difficulty to franchising businesses, both for the Thai franchising businesses and the ASEAN member's franchising businesses. The article concludes on the possible future development of the regulatory and commercial environment for the franchising in Thailand.

\section{BRIEF OVERVIEW OF THE REGULATORY FRAMEWORK OF THE FRANCHISING SECTOR IN THAILAND}

By the significant increase of international trade, franchising in Thailand is in a significant growing pace. Based on the development of SMEs in Thailand, franchising is an important means for expanding the SME sector. Foreign and local franchisors are extending their scope of businesses within the Thai economy and under a crucial preparation to serve the larger economy under the ASEAN market integration. However, with the larger breadth of the franchising sector, the regulatory framework is a vital factor to support and stimulate the growing pace of the franchising sector in Thailand. This part provides a brief overview of the regulatory

1 ASEAN, 'ASEAN Economic Community Blueprint' (ASEAN, 2008) Accessed April 20, 2016 <http://www.aseansec.org/5187-10.pdf> section p.5 Section Characteristics and Elements Of AEC.

2 International Franchise Association, (2015), 'What are common franchise term', Accessed April 20, 2016. http://www.franchise.org/what-are-common-franchiseterms. 
framework of the Thai franchising sector with focus on the following issues: 1) lack of unified legislation for franchising; 2) unfair business conducts; and 3) the draft Franchise Business Act and the government regulatory support.

\section{Lack of Unified Legislation for Franchising}

Thailand has yet to develop a unified legislation to regulate franchising. Franchising is still be kept under the Thai civil law system under the freedom of contract based on Thailand Civil and Commercial Code (ประมวลกฎหมายแพ่งและพาณิชย์) which is the main body of laws that deals with the legal affairs and rights of private persons (natural and juristic persons). ${ }^{3}$ The Civil and Commercial Code contains areas such as family law, inheritance law, contract law, property law, and corporate law. Thus, to go into the franchising business in Thailand, the main legislation that the franchisor and the franchisee have to take into consideration is the Thailand Civil and Commercial Code. Based on the code, any franchising agreement is a legally binding agreement which outlines the franchisor's terms and conditions adhering to the perception of freedom of contract. ${ }^{4}$ Thus, the Civil and Commercial Code is a cohort legislation that governs franchise relationships with a broad term of commercial operation or commercial relationship. In case of signing a franchising contract, there is a specific section of the Code - Chapter I Section 354-368 which prescribes a formation of contract that contracting parties have to adhere to. The contracting parties must also take heed of Chapter II Effect of Contract Sections 369-376. ${ }^{5}$ In a Thai supreme court case $(9753 / 2551)$ the court decided that under the Thai Civil and Commercial Code, Chapter II Effect of Contract Sections 369-376, the franchisee who contractually uses the franchisor's brands and

3 See the translation of the Thailand Civil and Commercial Code by Dr. Pinai Nanakorn Accessed $\quad$ April $\quad 2016$ http://www.dbd.go.th/dbdweb_en/more_news.php?cid=283\&filename=index.

4 Joel EE, 'Franchising in Thailand - Chapter 1: Things to Consider before Buying into / Selling a Franchise in Thailand' (2014) ,accessed April 20, 2016 http://bangkoklegal.wordpress.com/2012/07/27/franchising-in-thailand-chapter1-things-to-consider-before-buying-selling-a-franchise-in-thailand-with-shortforeword-on-thailand-asean-economy/.

5 Private Law in Thailand, April 20, 2016, http://www.thailandlawonline.com/table-of-contents/thai-private-law-the-civiland-commercial-code. 
services must transfer business profits to the franchisor as stipulated in the franchising contract. ${ }^{6}$

Moreover, as there is no current master legislation governing franchising in Thailand, the franchising businesses are also regulated by various legislation that govern general businesses activities. These legislation includes Patent Act B.E. 2522, Trademark Act B.E. 2534 (1991), and Trade Secrets Act B.E. 2545. The Patent Act B.E. 2522 is a law controlling and supporting new inventions capable of industrial application. ${ }^{7}$ According to the Patent Act BE 2522, the inventors can register their patents with the Minister of Commerce and can claim their right to apply for the patent. ${ }^{8}$ Franchisors with registered patents can then require the franchisee to use the patented innovation in the franchising businesses. In the Trademark Act, the franchisor can also control the franchisee in using its registered trademark ${ }^{9}$ under the agreements of their franchising businesses. The franchisor is able to exercise its rights over a franchisee's improper use of its trademark. Additionally, the Trade Secrets Act B.E. 2545 is purported to be a piece of legislation which protects the formula and other essential trade secrets of a franchisor. ${ }^{10}$ Any franchisee's act of disclosure, deprivation or usage of trade secrets without the consent of the franchisor in a manner contrary to honest trade practices are a breach of the Act. ${ }^{11}$ Therefore, franchising activities have to be governed by laws relating to intellectual property protection. The intellectual property laws tend to establish essential relationships between the franchisor and the franchisee with regard to the use of innovations, trademarks and trade secrets. In addition, the laws also protect both franchisors and franchisees where there is a breach of any intellectual property by third parties. This can be seen in "Starbung case" where the Starbucks Coffee (Thailand) Co., Ltd sued 'Starbung' - a street

6 Thai Supreme Court decision at (9753/2551), accessed April 20, 2016, http://thai-civil-code.blogspot.com/2009/08/blog-post_7226.html.

The Patent Act BE 2522 section 5.

The Patent Act BE 2522 section 4 and 10.

See Trademark Act B.E. 2534 section 4 that define the terms of mark and trademark as; "mark" is defined as a brand, name, word, letter, photograph, drawing, device, manual, signature, combinations of colors, shape or configuration of an object or any one or combination thereof; "trademark" is defined as a mark used or proposed to be used on or in connection with goods to distinguish those trademarked goods from other trademarked goods.

10 Trade Secrets Act B.E. 2545 section 5.

11 Trade Secrets Act B.E. 2545 section 6. 
coffee vendor - due to Starbung's logo being in violation of the Starbucks Coffee's registered trademark. ${ }^{12}$

\section{Unfair Business Conducts}

It is important to consider legislation that prohibit unfair business conducts. The legislation, prescribing prohibition on unfair business conducts are the Competition Act B.E. 2542 and Unfair Contracts Terms Act B.E. 2542. The Competition Act B.E. 2542 was passed as the main statute dealing with abuse of market competition. The Act contains important prohibiting rules dealing with abuse of market power, cartels and mergers and acquisitions. Section 25 of the Act deals with the abuse of market power by prohibiting businesses occupying a dominant market position from: i) operating in the manner of fixing prices of goods and services; ii) directly or indirectly tying sale for restricting free supply and demand of goods or services; and iii) intervening the operation of other businesses without reasonable objectives. ${ }^{13}$ In section 27, the Competition Act forbids the collusive and cartel agreements that have an effect on market competition. ${ }^{14}$ In section 28 , Thai competition law proscribes business entities to enter into an international agreement or a conduct that deters market competition by limiting opportunities to purchase goods or services from business operators outside Thailand. Thus, when considering franchising activities where there is a possibility of the franchisor having dominant power that controls franchisees in the market, there may be infringement of the Thai Competition Act. In addition, where there is an agreement between the franchisor and the franchisee regarding price or geographical sales, there must be a consideration of the Competition Act as the agreement may amount to prohibited cartel conducts.

\footnotetext{
12 Jon Fernquest, "Starbungs vs. Starbucks: Billion dollar corporation vs. street vendor" Bangkok $\quad$ Post, 18 Oct 2013, http://www.bangkokpost.com/learning/learning-from-news/375260/starbungsvs-starbucks-billion-dollar-corporation-vs-street-vendor.

13 Thai Competition Act 1999 section 25 subsection 1,2,3 and 4.

14 Thai Competition Act 1999 section 27; see more detail in the Act.
} 
However, it is noted that the Thai Competition Act is seeing an ineffective phase due to the fact that there has not been any court case regarding infringement of the Act. ${ }^{15}$

In entering into a franchising agreement, there is also concern over the Unfair Contracts Terms Act B.E. 2542. The franchisor in making agreement has to make sure that the terms in the contract will not constitute an unfair condition rendering the franchisor's unreasonable advantage over the franchisee. ${ }^{16}$ The example of unfair condition is a condition rendering the contract to be terminated without justifiable ground or granting the right to terminate the contract despite the franchisee not being in breach of any essential part of the contract. ${ }^{17}$ Thus, the franchisor, in stipulating any conditions to its franchising agreements, has to pay attention to prohibitions under the Unfair Contracts Terms Act B.E. 2542. ${ }^{18}$

\section{Draft Franchise Business Act and Government Regulatory Support}

As there is still no specific legislation for franchising in Thailand, the Thai Ministry of Commerce has proposed the draft Franchise Business Act to the Parliament with an aim to make the proposed Act as a main legislation to promote franchise businesses in Thailand. While the proposed Act has been put to the parliament's consideration since 2010, the Act has still not been passed. This may be because of political uncertainty. The draft Act proposes establishment of the Franchise Business Commission and sets out rules for operating franchise businesses in Thailand. The draft in section 9 states that there will be an establishment of the Franchise

15 Wisuttisak, P., 'Ineffective Competition Law: A Case from Thailand' (Paper presented at the Asian Competition Forum Annual Conference: Establishing Sound Competition Cultures in Asia, Hong Kong, 2011); Wisuttisak, P., "Liberalisation of Thai Energy sector: a consideration of competition law and sectoral regulation," Journal of World Energy Law \& Business 5, no. 1, (2012): 60-77.

16 Unfair Contract Terms Act BE 2542 section 4.

17 Unfair Contract Terms Act BE 2542 section 4 (3)

18 Is a revocation of unfair franchising contract possible? ข้อตกลงสัญญาแฟนไชส์ไม่เป็นธรรม เพิกถอนได้หรือไม่, accessed April 20, 2016, http://www.sme.go.th/Lists/EditorInput/DispF.aspx?List=15dca7fb-bf2e-464e97e5-440321040570\&ID=1741. 
Business Commission having duties to oversee franchise businesses ${ }^{19}$ and to issue regulation in order to support the development of franchising in Thailand. ${ }^{20}$ The draft also plans to establish the support office for the Franchise Business Commission under the Department of Business Development, Ministry of Commerce. The office will have duties as a complaint-receiving agency and an administrative agency for the Commission. ${ }^{21}$ In addition, in case the draft is passed, all franchising businesses are required to be registered with the office of the Franchise Business Commission. ${ }^{22}$ Also, basing on the draft, all franchising contracts have to be based on the prescribed rules. The draft stipulates that the franchise contract must have the content prescribed by Ministry of Commerce. ${ }^{23}$ All franchise contracts also have to be in writing. ${ }^{24}$

In the context of drafting the Act, the Ministry of Commerce has commented that the passing of the Franchise Business Act is essential to the franchise sector. The franchising businesses, both domestic and foreign, are rapidly growing. The Act would be the legislation that would help to promote the development of the franchise sector as well as maintain the fair business conduct in the franchising businesses. ${ }^{25}$ When considering the ASEAN integrating market, the Franchise Business Act will be an important Thai legislation to regulate the franchising business in Thailand and ASEAN. Nevertheless, it is noted that while there is considerable need for the Thai Franchise Business Act, the outcome of passing the Act is still unclear. ${ }^{26}$

Apart from the draft Franchise Businesses Act, it is important to focus on the SMEs Promotion Act, B.E. 2543. The SMEs Act is purported to be a regulatory support to SMEs development in Thailand. Taking into consideration the franchising sector, the Act is a current regulation governing and stimulating the enhancement of the Thai franchising sector. The SMEs Promotion Act, B.E. 2543 provides that there is a SMEs Promotion Commission and the office

\footnotetext{
Draft Franchise Business Act section 13 (2).

Draft Franchise Business Act section 13 (3).

Draft Franchise Business Act section 17.

Draft Franchise Business Act section 19.

Draft Franchise Business Act section 23.

Draft Franchise Business Act section 24.

Thai Law Amendment Agency, 2010, accessed April 20, 2016, http://www.lawamendment.go.th/index.php/laws-independent-entity/item/351topic_351.

26 Joel EE, 'Franchising in Thailand'.
} 
of SMEs Promotion. The commission and office would then be a cohort agency for:

- Formulating SMEs Promotion Master Plan and SMEs Promotion Action Plan;

- Propelling, supporting and developing the SME promotion systems and integrating the SME promotion works of all public and private agencies;

- Developing SME knowledge and database to support SME policy recommendations and SME promotion work;

- Administering the SMEs Promotion Fund so as to be a tool for an effective SME promotion. ${ }^{27}$

Therefore, the SMEs Promotion Act, B.E. 2543 (2000) is a vital regulatory framework to promote SMEs, especially franchising businesses in Thailand.

\section{THAI FRANCHISING SECTOR UNDER THE ASEAN INTEGRATING MARKET}

The first part of the article has explored the brief overview of the legal framework for the franchising sector in Thailand. The first part shows that there is a lack of unified laws and regulations, though there is support for the franchising sector via a policy and other laws. This leads to a possible concern where there is a significant expansion of the Thai franchising sector. While there is a lack of unified law, the franchising sector in Thailand is growing. The issue at this point is that the growing sector lacks the necessary specific legal mechanism to regulate it. It is evident that the franchising businesses in Thailand are experiencing expansion in line with the ASEAN integrating economy. This part of the article focuses on two main aspects, namely: 1) The expanding franchising sector in Thailand; and 2) Potential Thai franchise market under the AEC.

\section{Expanding Franchising Sector in Thailand}

27 The Thai Office of SMEs Promotion, Vision and Mission: Authority Stipulated by the SMEs Promotion Act, B.E. 2543 (2000) http://www.sme.go.th/eng/index.php/about-osmep/vision. 
The franchising sector is expected to rapidly expand in Thailand. According to a report from International Franchise Association (IFA), the Thai franchising sector has been expanding approximately 20 percent annually and is predicted to grow further. ${ }^{28}$ The reason behind the expanding franchising sector in Thailand is there are significantly increasing young and aspiring entrepreneurs who favour the franchising businesses. ${ }^{29}$ Similarly, in the report from US Department of Commerce, the Thai franchise industry is still a preferred business among Thai investors due to an attractive and relatively safe form of investment. ${ }^{30}$ In 2010, there were 514 franchisors of which 90 percent were local franchising. ${ }^{31}$ The important factor which helps expand the franchising sector is the government policy to promote Thai SMEs. ${ }^{32}$ The Thai government has realised that franchising through SMEs is a fast way to facilitate the development of the SMEs sector which is essential to long term economic development. ${ }^{33}$ The government has set up a loan policy to support SMEs under the SMEs fund and by the establishment of the SMEs Bank Thailand. The Thai government has played a major role in providing financial assistance to SMEs by establishing target loans given through the Specialized Financial Institutions (SFIs). ${ }^{34}$ The government has also set up the "Small-Industry Credit Guarantee Corporation" so as to allow guaranteed credit lines for a greater number of SMEs. ${ }^{35}$ The SMEs in the franchising businesses are able to seek financial support from the SMEs Bank. The SMEs Bank was

28 International franchise Association, 2014, Franchise market Overview-Thailand, http://www.franchise.org/uploadedFiles/Franchise\%20Market\%20Overview_Th ailand.pdf.

29 Ibid.

30 US Department of Commerce, 'Doing Business in Thailand: 2012 Country Commercial Guide for U.S. Companies' (US Department of Commerce, 2012) accessed March 20, 2016, http://citd.org/wp-content/uploads/2013/06/Thailand2012-CCG.pdf.

Ibid.

See, The Thai Office of SMEs Promotion,

Ibid.

34 Chaipat Poonpatpibul and Watsaya Limthammahisorn, 'Financial Access of SMEs in Thailand: What Are the Roles of the Central Bank?' (Bank of Thailand Conferencce, 2005) accessed March 20, 2016 http://econ.tu.ac.th/class/archan/RANGSUN/EC $\quad 460 / E C \quad 460$ Readings/เอกสารและสิ่งตีพิมพ์ธนาคารแห่งประเทศไทย/Discussion Paper/Financial Access of SMEs in Thailand.pdf. Ibid. 
established by the government to offer a supportive financial institution for SMEs. ${ }^{36}$ The SMEs, especially in the franchising sector, are able to seek financial assistance in terms of a loan, bank guarantee, and other financial services from the SMEs bank. ${ }^{37}$ In addition, a variety of harmonized government policy and mechanisms which have stimulated the expansion of the SMEs sector have resulted in the expansion of franchising businesses in Thailand. This is seen from the diagram below.

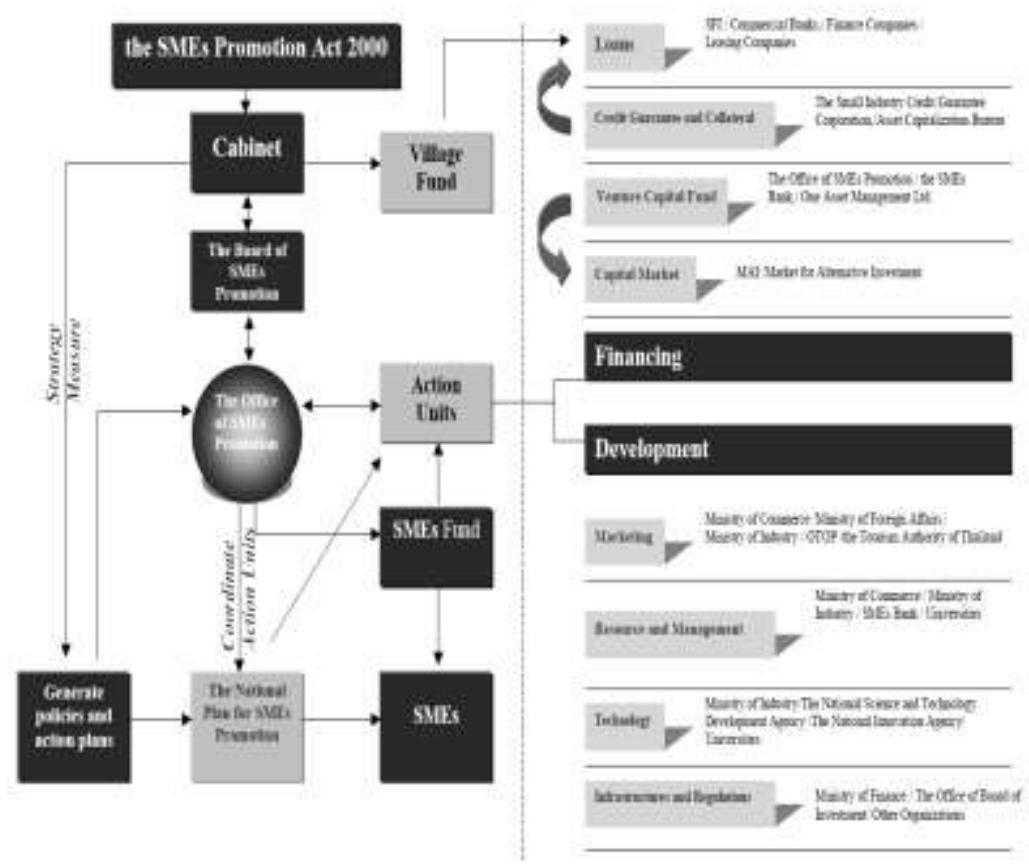

Figure 1: Strategic Planning Structure of SMEs Promotion Policy ${ }^{38}$

Given the strong government support for SMEs, the franchising businesses in Thailand seem to have promising opportunities. There

36 SMEs Bank Thailand, About SMEs Bank Thailand, Accessed March 20, 2016, http://www.smebank.co.th/en/about.php.

37 SMEs Bank Thailand, SMEs Bank Thailand-Services accessed April 20, 2008, http://www.smebank.co.th/en/service-deposit.php.

38 Source: Poonpatpibul, Chaipat and Watsaya Limthammahisorn, 'Financial Access of SMEs in Thailand: What Are the Roles of the Central Bank?' (Bank of Thailand Conference, 2005). 
are currently more than 400 franchisors (majority foreign-owned) and more than 10,000 franchisees in Thailand. ${ }^{39}$ Most franchise operations take place in the food and restaurant sector, followed by services, education, and retailing. However, the local franchises have better growth potential than international franchises. ${ }^{40}$ The majority of foreign franchise systems are US franchisors including McDonalds, Burger King, Starbucks, Au Bon Pain, KFC, Pizza Hut, Krispy Kreme, Baskin Robbins, A\&W, Subway, Outback Steak, Sizzler, Dunkin' Donuts and Gymboree. ${ }^{41}$ It is noted that while the local franchising businesses have higher growth and higher market shares than foreign franchises, the capital value of foreign franchise is much greater than Thai local franchises.

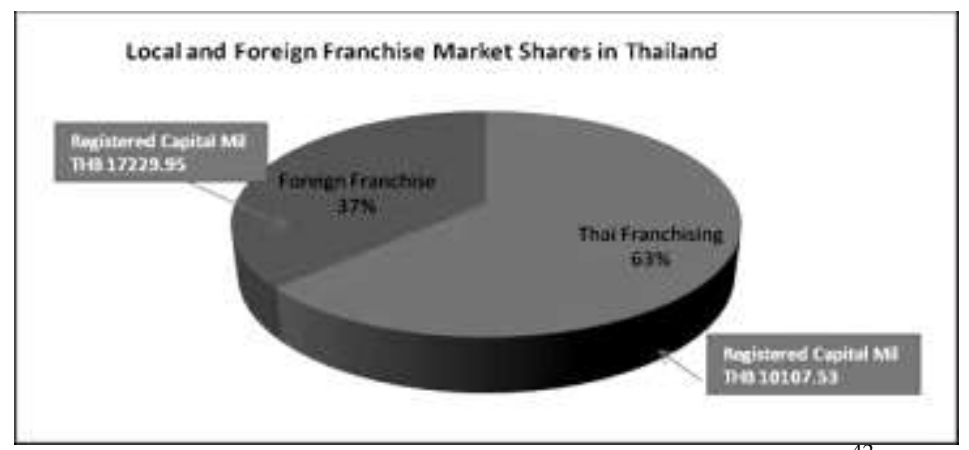

Figure 2: Local and Foreign Market Shares in Thailand ${ }^{42}$

\section{Potential Thai Franchise Market under AEC}

In 2007, the ASEAN member states unanimously consented to the Declaration on the ASEAN Economic Community Blueprint which is a main cooperation plan to facilitate the ASEAN market integration.

39 Alan Adcock, 'Franchising in Thailand - Some Current Issues' (2011) $<$ http://www.tilleke.com/resources/franchising-thailand-\%E2\%80\%93-somecurrent-issues>

40 US Department of Commerce, 'Doing Business in Thailand: 2012 Country Commercial Guide for U.S. Companies'

41 Ibid.

42 International Institute for Trade and Development (ITD), 'Strategic Development for Thai Franchising toward International Market: Development Plan for Franchise Opportunities (การพัฒนากลยุทธ์การตลาดธุรกิจแฟรนไชส์สู่สากล ภายใต้โครงการพัฒนาและสร้างโอกาสทางการตลาดธุรกิจแฟรนไชส์)' (Thai Department of Business Development, 2013). 
The blue print sets up a solid timeframe for all ASEAN members to jointly complete integration of the ASEAN economic community in $2015 .^{43}$ The blueprint also urges all members to transform ASEAN into a region with free movement of goods, services, investment, skilled labour, and freer flow of capital. ${ }^{44}$ Thus under the current pace toward free flow of trade and services in ASEAN, franchising from Thailand would gain considerable opportunities as well as meet with significant challenges.

Under the AEC, Thai franchisors or foreign franchisors operating in Thailand would be able to meet with the lucrative ASEAN market where there is a population around 616 million people and GDP of US\$ 2.3 trillion. $^{45}$ The ASEAN trade intra-value is at around US\$ 602,048 million with the trade balance of US\$ 32,734 million. The potential growth of ASEAN seems to be very promising and is seeing rapid increase of consumptions in goods and services. This is reflected in the data from the graph below. It is also shown that the ASEAN economic integration will be a possible cow for businesses to milk. Thus, for the franchisors based in Thailand, the ASEAN integrating market is a potentially profitable market with the opportunities to expand franchise branches.
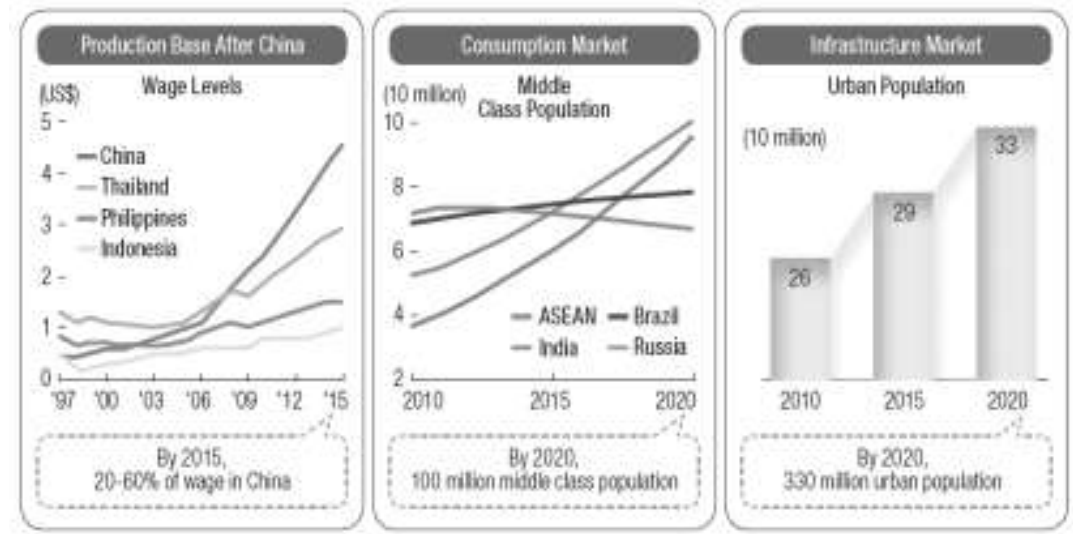

43 ASEAN, 'ASEAN Economic Community Blueprint' (ASEAN, 2008) <http://www.aseansec.org/5187-10.pdf> accessed on 19 May 2012

44 Ibid.

45 ASEAN, 'ASEAN Community in Figures (ACIF) 2013 ' (ASEAN, 2013) http://www.asean.org/images/resources/2014/May/2.\%20Feb\%202014\%20$\% 20$ ASEAN\%20Community\%20in\%20Figures\%202013.pdf. 
Figure 3: Comparative Graph of Attractiveness of the ASEAN Economy ${ }^{46}$

The example is in the franchising of the food and beverages sector. Boonprasert Pupan, managing director of N\&B Pizza Crepe Co $(\mathrm{N} \& \mathrm{~B})$, Thailand, presented that the $\mathrm{N} \& \mathrm{~B}$ plans to launch franchise businesses in other ASEAN countries - mainly Singapore, Malaysia, Myanmar, Laos and Cambodia - in 2016. N\&B currently spread its franchise over 105 branches nationwide, including in Nong Khai across from Laos, Hat Yai in Songkhla across from Malaysia, Mae Sot and Tak across from Myanmar, and Sa Kaew across from Cambodia. ${ }^{47}$ Another example is from the Thai Minor Food Group (Minor). The Minor owns and franchises 10 brands with more than 1,000 restaurants in 13 countries across Asia. In 2009, the Minor Food Group's of companies owned and franchised restaurants and had sales greater than US\$ 550 million. ${ }^{48}$

However, the opportunities by ASEAN integration come with great challenges for the Thai franchising sector. The franchisors in Thailand are less prepared for international competition with key weaknesses in several areas such as law, accounting and professional business administration. ${ }^{49}$ Likewise, many franchisors also lack knowledge and financial management which are important to be sustained in operating businesses overseas. ${ }^{50}$ The challenges also lie with a gap on economic development. While gaining high opportunities from the late-coming ASEAN member countries like Cambodia, Laos, Myanmar and Vietnam (CLMV), the franchisors in Thailand also face high business risks when entering into these markets. In order to expand branches in the CLMV, the franchising

46 Source: Kyung-Hoon, Kim, 'The Potential of ASEAN Revisited' (2013) April SERI Quarterly.

47 Petchanet Pratruangkrai, 'Franchises target AEC', The Nation Thailand (Bangkok), 2014 .http://www.nationmultimedia.com/business/Franchises-targetAEC-30241996.html.

48 'Minor Food Group, About us' Accessed http://www.minorfoodgroup.com/aboutus/index.html.

49 Phusadee Arunmas, 'Thai franchise not ready to go abroad', Bangkok Post 29 August 2014 ,http://www.bangkokpost.com/business/news/429291/franchiseoperations-not-ready-to-compete-abroad.

50 Petchanet Pratruangkrai, 'Franchises urged to think international', The Nation Thailand 12 Aug 2014, http://www.nationmultimedia.com/business/Franchisesurged-to-think-international-30240704.html. 
business would have to carefully consider the potential financial, political, and legal risks in the CLMV. ${ }^{51}$

\section{ASEAN INTEGRATING MARKET AND INTERNATIONAL CONNECTION}

There is also greater chance for Thai franchising go beyond the ASEAN market towards the international economy. This is due to the fact that ASEAN has embarked on various Free Trade Agreements (FTAs) which are a promising legal ground facilitating trade and investment flow of ASEAN and its FTAs partners. The FTAs that ASEAN has established are:

1. China-ASEAN Free Trade Agreement (CAFTA)

2. ASEAN-India Trade in Goods Agreement/ASEAN-India Free Trade Agreement (ASEAN-India TIG/AIFTA)

3. ASEAN-Japan Comprehensive Economic Partnership Agreement (AJCEPA)

4. ASEAN-Korean Free Trade Agreement (AKFTA)

5. ASEAN-Australia-New Zealand Free Trade Agreement $(\text { AANZFTA })^{52}$

The ASEAN FTAs above open a promising business window for franchisors in Thailand. The franchisors will be able to tap the ASEAN integrating economy and enhance their businesses with ASEAN FTAs parties. In addition, the ASEAN is on the move to support intra-market integration which connects with the global market. According to the recent ASEAN report on "Thinking Globally, Prospering Regionally - ASEAN Economic Community 2015", ASEAN are aiming at developing its regional market integration as well as at merging ASEAN with the global market. ${ }^{53}$ ASEAN states affirm commitment that it will move to a market integration of Equitable Economic Development and to the globalized

\footnotetext{
51 Kim Kyung-Hoon, 'The Potential of ASEAN Revisited'.

52 Thai FTA, Accessed March 20, 2016, http://www.thaifta.com/ThaiFTA/.

53 ASEAN, 'Thinking Globally, Prospering Regionally - ASEAN Economic Community 2015' (ASEAN, 2014) Accessed March 13, 2016, http://www.asean.org/images/resources/2014/May/AECKeyMessagesBooklet_F INAL30Apr2014.pdf
} 
economy. ${ }^{54}$ Under ASEAN policy to join the global market, the franchising sector is gaining enormous opportunities to expand their franchise businesses in ASEAN and the global economy. The example is from Thai CP All PCL (CP). The CP has rapidly expanded its 7-Eleven convenience store chain in Thailand. ${ }^{55}$ The $\mathrm{CP}$ is under a strategic plan to move forward its chain to neighbouring countries such as Myanmar, Laos, Cambodia, Vietnam and to the larger market in China. ${ }^{56}$

The above discussion shows a potential expansion of the Thai franchising sector within the ASEAN context. However, it is of great concern that there is a lack of unified franchising regulation in a situation where to govern and support the expansion of the franchising sector in Thailand.

\section{THE THAI FRANCHISING ENVIRONMENT IN COMPARISON WITH OTHER ASEAN MEMBERS}

Thailand is lagging behind the other ASEAN members with regard to preparation of unified regulation for the franchising sector. There is therefore a need for adoption of legislation for franchising sector as is the case with other ASEAN members, like Malaysia, Indonesia and Singapore.

Thailand seems to lag behind Indonesia in terms of preparing a legal mechanism for the franchising sector. Indonesia, in an effort to facilitate the development of the franchising sector, has issued the Minister of Trade Regulation No. 53/M-DAG/PER/8/2012 on Franchise Management and the Minister of Trade Regulation No. 68/M-DAG/PER/10/2012 on Franchise of Modern Retail Stores. ${ }^{57}$ Those regulations are important legal grounds for creating a more favourable environment for the franchising sector in order to support

\footnotetext{
54 Ibid.

55 Payungsak Wiriyabunditkul, 'Thailand's 7-11 Operator Eyes Expansion to China, Neighboring Countries ', Wall Street Journal 31 Jan 2013 http://blogs.wsj.com/searealtime/2013/01/31/thailands-7-11-operator-eyesexpansion-to-china-neighboring-countries/.

56 Ibid.

57 ASEAN-China Organisation, 'Franchise Regulation : The Ministry of Trade Supports Development of SMEs' (2013), Accessed March 13, 2016, http://www.asean-cn.org/Item/7041.aspx.
} 
new entrepreneurs in franchising ${ }^{58}$ However, the regulation also leads to obstacles for franchising as regulation 53 requires franchising business to: i) use local components for at least $80 \%$ of the raw materials and ii) to register with the Minister of Trade. ${ }^{59}$ Through this regulation, the government aims to support Indonesian local raw materials, domestic equipment, or even local consumer goods. ${ }^{60}$ While the regulations may cause more legal requirements to business, Indonesian franchising sector is in a promising position as the sector maintains high levels of growth. ${ }^{61}$ Thus, compared to Thailand, Indonesia seems to have developed unified legal codes that help govern and support the franchising sector with the increasing growth of the franchising sector.

Similarly, Thailand is behind Malaysia in developing a legal framework for the franchising sector. Malaysia, as a country having a fast growing franchising sector, passed its legislation to standardise and support expansion of the franchising sector. The Malaysian Franchise Act 1998 (Amendment 2012) has provided various requirements with the intention of building franchising standards in Malaysia. The Act requires franchising businesses to be registered with the Registrar of Franchise (ROF). ${ }^{62}$ It is an offence to use the term "franchise" or any of its related words which indicate the operation of a franchise business as part of the name or title without the Registrar's prior permission. ${ }^{63}$ In addition, with regards to government support for fast growing franchise businesses in Malaysia, the government has put in place various mechanisms to support the growing pace of the franchising businesses. The Malaysian government provides a support program and soft loan for

58 Ibid.

59 Graeme Payne and Gordon Drakes, 'New franchise regulations in Indonesia: A fine line between stimulating the local market and protectionism' (2013) 11(1) International Journal of Franchising Law.

60 ASEAN-China Organisation, 'Franchise Regulation.

61 William Edwards, 'Expanding Markets-Franchising in Viet Nam and Indonesia' (2011), Accessed March 20, 2016, http://www.franchise.org/Franchise-IndustryNews-Detail.aspx?id=55678.

62 Chew Kherk Ying, Sonia Ong and Chen Hong Sze, 'Franchise (Amendment) Act 2012' (Wong \& Partners, 2012) http://www.wongpartners.com/files/Uploads/Documents/Type\%202/WP/al_won gpartners_franchiseamendmentact_dec12.pdf.

63 Su Siew Ling, 'Changes To Franchise Law In Malaysia' (Tay \& Partners, 2013) Accessed 20 March 2016, http://www.taypartners.com.my/v5/download/insidertaps-20130108.pdf. 
newly revised SMEs, including franchise businesses. Thus, compared to Thailand, Malaysia is in a better position in preparation of unified rules for the franchising sector in Malaysia under the ASEAN market. The Malaysian government also puts forward mechanisms to help boost SMEs which are the core of franchise businesses.

In Singapore, like Thailand, there is no specific legislation for the franchising business. However, the governance of the franchising sector in Singapore is far superior to that in Thailand. Singapore is one of ASEAN's strongest franchising markets. ${ }^{64}$ This is because there is good development of legal rules for businesses in Singapore. According to Singapore Franchising and Licensing Association (FLA), there are less legal disputes in the franchising sector. ${ }^{65}$ The main resolution in case there is conflict is by amicability between the franchising parties, and hardly any make it to the courts. ${ }^{66}$ This franchising environment can be attributed to the excellent legal development found in Singapore. In addition, the franchising sector in Singapore is self-regulated and the instrument of regulation is by the FLA Code of Ethics which is applies to members of the FLA. ${ }^{67}$ Therefore, the Singapore franchising sector is in a better position than Thailand. This is a good legal framework shaping the franchising sector, although there is no specific legislation for the sector. It seems that Singapore is in a higher position than Thailand in preparing the franchising sector for the coming ASEAN market integration.

\section{THAI FRANCHISING REGULATION AND COMMERCIAL ENVIRONMENT: A POSSIBLE SUGGESTION}

From the above, it is important for Thailand to prepare its specific laws for the franchising businesses. Compared to Malaysia and Indonesia, Thailand has not adopted any specific law or regulation

64 Thailand pushes for more franchising across borders, Accessed March 2 2016, http://www.asianews.network/content/thailand-pushes-more-franchising-acrossborders-10769.

65 Singapore Franchising and Licensing Association (SFLA), 'Franchising in Singapore' (2014), Accessed March $20 \quad$ 2016, http://www.flasingapore.org/archive_legal1.php.

66 Ibid.

67 Constance Leong, 'The Legal Environment of Franchising in Singapore and a Comparative Overview of Franchise Laws in Some Other Countries' (2011), Accessed March 20, 2016 ,http://www.lawgazette.com.sg/2011-03/42.htm. 
which helps to regulate the franchising sector. When there is an expansion of the sector under the ASEAN integrating market, the franchising sector may be subjected to various rules and may find legal difficulty as to ensure the smooth operation of the franchising business. According to Prof. Andrew, the franchising requires a healthy underlying law to support its orderly development. ${ }^{68}$ The various legislation governing the franchising business can create confusion for preparation of franchising and operation of a franchising business. ${ }^{69}$ The development of the expanding franchising sector in Thailand thus requires a specific law. It has been observed that a specific franchising law is necessary because the law helps deal with problems on the right balance between the parties to a franchising agreement and to make sure that abuses of the agreement either do not occur or, where they have occurred, that they do not occur again ${ }^{70}$. It is proposed therefore that Thailand has to adopt a specific law for the franchising sector so as to ensure conformity with the legal position of adopting a specific law for the franchising business in other ASEAN member countries. The adoption of a Thai franchising law would also assure that there is legal mechanism that helps to shape the franchising businesses. The draft Thai franchising law is a promising piece of legislation. The next step is to pass the draft legislation.

While it is opined that specific legislation is to be adopted in Thailand, it is observed that Singapore has not adopted any specific regulation for the franchising sector. The difference between Thailand and Singapore is that there is a self-regulation mechanism in Singapore and the common law system has help filled up a legal gap for governing the franchising sector in Singapore. As provided above, the Singapore Franchising and Licensing Association is the main organisation governing the franchising business in Singapore. The association provides a franchising code and ethics for its members. ${ }^{71}$

68 Andrew Terry, 'A Comparative Analysis of Franchise Regulation in Asia' (Paper presented at the 16th Annual Conference of International Society of Franchising, Orlando, Florida, the USA, 2002).

69 Nguyen Ba Binh, 2013, "The Role and Influence of Vietnam's Franchise Law on the Development of Franchising: a Multiple Case Study", $\mathrm{PhD}$ thesis University of New South Wales, Sydney, Australia, p 120-121.

70 Lena Peters, 'UNIDROIT Prepares a Model Franchise Disclosure Law' (2000) Business Law International 279.

71 Franchising and Licencing Association of Singapore, 2015, Accessed March 13, 2016, http://www.flasingapore.org/files/FLA\%20Code\%20of\%20Ethics.pdf. 
The code and ethics function as a customs and self-governing rules for the franchising sector in Singapore. The self-governance of franchising in Singapore is thus different from Thailand where the Thai Franchising associations are not effective and are not unified as one single association. There are at least three franchising associations in Thailand and the associations are mainly established as a main forum for operating a franchising business but not as a main entity for creating governing rules. ${ }^{72}$ Moreover, Singapore has its common law system in which a court can apply their discretion to cases where there is a gap in legislation. In considering a dispute in the franchising sector without a specific law on franchising, Singaporean courts may refer to various international cases and apply their discretion to resolve the dispute in the franchising sector. ${ }^{73}$ This is different from Thailand which has a civil law system. The Thai court must have legislation at hand before making any decision. Thus when having to cope with cases relating to franchising businesses, the Thai court must rely on various legislation which may not accommodate the fast changing franchising businesses.

Given that the franchising sector is expanding in Thailand and considering the opportunities offered by the larger ASEAN integrating market, it is seriously believed that Thailand should adopt specific law for governing franchising sector. In case the establishment of the specific law for franchising is a difficult task, preliminary preparation for the governance of the Thai franchising sector is needed. For this purpose, it is proposed that there must be an establishment of an authoritative power to the Department of Business Development under Ministry of Commerce. The authoritative power to the department is proposed as a short term plan when there is a lack of unified legislation for Thai franchising sector. The Department has initiated the move to regulate the Thai franchising business by proposing a "Model Agreement for Franchising" in Thailand. ${ }^{74}$ However, the Department does not have an authoritative power to control and govern details of the franchising

72 See the three Thai Franchsing Association from the website of Franchise and License Association (Thailand), Thai Franchise Center and Franchise Focus Thailand.

73 Singapore Academy of Law, 2015, Commercial Law, Accessed March 13, 2016,http://www.singaporelaw.sg/sglaw/laws-of-singapore/commercial-law.

74 Department of Business Develop Ministry of Commerce, Thailand, 2015, "Model Franchise Agreement", <http://www.dbd.go.th/ewt_dl_link.php? $\underline{\text { nid }=9685}$.> 
business. The model agreement is only a guideline for a franchising agreement, whilst there are various aspects of the franchising business that require regulatory governance. Examples include dispute resolution mechanisms, how to deal with an unfair agreement, breach of the franchising agreement, and unconscionable conducts in franchising. Thus, in case the passing of a unified law on franchising is difficult, it is proposed that in the short run there must be an authorization of power to the department which will help in acting as a government agency which can govern and control the franchising business in Thailand.

\section{CONCLUSION}

The article presents the Thai regulatory and commercial environments for franchising. There is a lack of unified legislation to regulate the franchising sector. The franchising arrangement has to be under the Civil and Commercial Code and other legislation such as the Unfair Contracts Terms and the intellectual property laws. There is a draft Franchise Business Act but the draft is still under long consideration. However, the Government provides various supportive mechanisms for the franchising business. This helps to boost franchising development and expansion of the franchising sector as SMEs in Thailand. With consideration of the ASEAN integrating market, Thai franchisors or foreign franchisors based in Thailand are able to move forward under the integrative enlargement of the ASEAN market. Notwithstanding this however, the franchisors will have to face regional challenges as there will be more competition from other franchising businesses. Nevertheless, comparatively in regard to the regulatory and commercial environment of other ASEAN member countries, Thailand seems to have less preparation for its regulatory governance of the franchising sector. It is proposed therefore that the draft unified law on franchising in Thailand should be passed soon. The law would help support and help govern the franchising businesses in Thailand with an expanding market in the ASEAN economy. In case the establishment of the law is a challenging task, it is proposed that the second best short term plan is to confer authoritative power to the Department of Business Development. The Department can then act as an agency to govern and promote the franchising sector in Thailand. 